\title{
THE DETERMINANTS OF HOUSEHOLD CREDIT IN SBAIN
}

Fernando Nieto

Documentos de Trabajo N. 0716

\section{BANCOUESPANA}

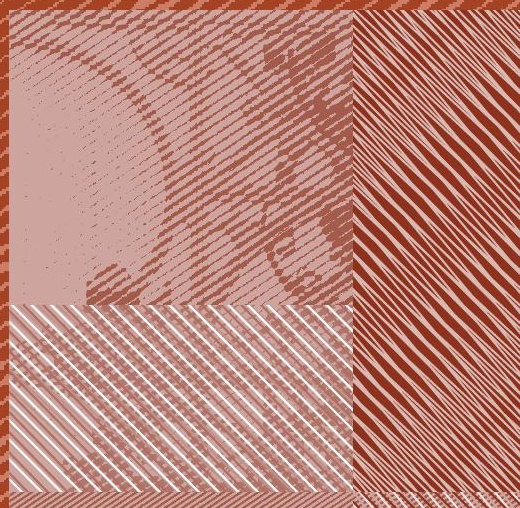

\author{
Eurosistema
}


THE DETERMINANTS OF HOUSEHOLD CREDIT IN SPAIN 
THE DETERMINANTS OF HOUSEHOLD CREDIT IN SPAIN

Fernando Nieto $\left(^{*}\right)\left(^{\star \star}\right)$

BANCO DE ESPAÑA

(*) Monetary and Financial Studies Department. Directorate General Economics, Statistics and Research. E-mail: fnieto@bde.es.

$\left.{ }^{(*}\right)$ I gratefully acknowledge the help and comments from Fernando Restoy, Juan Ayuso, Roberto Blanco, Luis Á. Maza and an anonymous referee. I also thank participants in the seminar held at the Banco de España. The opinions in this paper are the responsibility of the author and, therefore, do not necessarily coincide with those of the Banco de España. 
The Working Paper Series seeks to disseminate original research in economics and finance. All papers have been anonymously refereed. By publishing these papers, the Banco de España aims to contribute to economic analysis and, in particular, to knowledge of the Spanish economy and its international environment.

The opinions and analyses in the Working Paper Series are the responsibility of the authors and, therefore, do not necessarily coincide with those of the Banco de España or the Eurosystem.

The Banco de España disseminates its main reports and most of its publications via the INTERNET at the following website: http://www.bde.es.

Reproduction for educational and non-commercial purposes is permitted provided that the source is acknowledged.

\section{(C) BANCO DE ESPAÑA, Madrid, 2007}

ISSN: 0213-2710 (print)

ISSN: 1579-8666 (on line)

Depósito legal: M.31024-2007

Unidad de Publicaciones, Banco de España 


\begin{abstract}
This paper estimates a single-equation model to analyse the main explanatory factors behind changes in Spanish household credit, considering that the behaviour of its determinants is exogenous. According to the evidence reported, household borrowing is determined in the long run by real spending, gross wealth and the repayment term for outstanding credits, which have a positive influence, and by the cost of loans and the unemployment rate, the effect of which is of a negative sign. Developments in the short run are influenced by changes in long-term interest rates and in employment. The evidence offered suggests that, in general terms, the financing received by households over the period analysed is in line with what may be inferred from its determinants; however, the high volume of debt incurred entails greater exposure of the sector to unexpected changes in its income, in its wealth or in the cost of borrowing, especially in a setting in which floating-rate loans are increasingly significant.
\end{abstract}

JEL classification: C53, E51, R20.

Keywords: Credit, Household, Error correction. 


\section{Introduction and motivation}

In the past decade, credit extended to households ${ }^{1}$ by resident financial institutions (the main source of financing for this sector) has expanded rapidly, with annual average growth of close to $17 \%$, which has entailed a significant increase in Spanish household indebtedness.

As Chart 1 shows, the high rate of increase of funds raised by households, mainly for property purchases, has led the sector's debt as a percentage of its disposable income to triple during the period under study, standing in 2006 at around 120\%. Despite the strong increase in indebtedness, the decline in the cost of borrowing and the lengthening of loan repayment terms have meant that the behaviour of the associated debt burden ${ }^{2}$ has not been so expansionary. Nonetheless, these developments have been against a background in which household saving has declined considerably, thus compressing the buffer available to withstand unexpected shocks.

Against this backdrop, it is very important to analyse the behaviour of household borrowing and its possible consequences for the economy's macroeconomic and financial stability $^{3}$. On one hand, a rapid increase in the sector's debt may be conducive to the emergence of demand pressures that then take the form of inflationary pressures. On the other, a very high level of debt will diminish households' responsiveness to potentially unexpected changes in their wealth, their income or in interest rates, contributing to heightening the effects that an adverse economic shock would have on their consumption and investment decisions ${ }^{4}$. At the same time, a very large volume of debt bears on the level of risk withstood by banks, potentially impacting the soundness of the financial system as a whole in the face of debt default situations.

However, the implications of growth in borrowing may differ depending on the explanatory factors behind such growth. It is reasonable to think that a substantial portion of the recent growth in Spanish household credit has been structural, mirroring the new macroeconomic environment in place since Spain joined the euro area. Characterising this have been a most sizeable reduction in interest rates, highly buoyant economic activity and a more stable macroeconomic environment, which has entailed substantial job creation and the maintenance of relatively high levels of spending (see Chart 2). At the same time, the development of the Spanish financial sector has also harboured factors which, on the supply side, may have allowed the level of the sector's debt to rise. For instance, greater competition may have exerted downward pressure on borrowing costs and improvements in risk management over time have been propitious to the lengthening of loan maturities.

As a result of the foregoing, tools are needed, first, to help analyse that part of household credit developments which may be explained fully by the behaviour of the

\footnotetext{
1. Includes private non-profit institutions serving households.

2. The means of calculating this concept can be found in Del Río (2002).

3. See, for example, Davis (1992), Malo de Molina and Restoy (2004) or Nieto et al. (2001).

4. For greater details on the effects that an excessive level of debt may have on consumption, see Martínez-Carrascal and del Río (2004).
} 
determinants of this variable; and further, to qualify potential financial risks associated with different future scenarios for the trend of the main macroeconomic variables ${ }^{5}$.

To conduct an appropriate analysis of household borrowing, this variable must be set in relation to the relevant real variables, as both are jointly determined. However, integrating a fully developed financial block into a general macroeconomic model makes the design of the model analytically complicated, and poses significant problems for the proper aggregation of the behaviour of individual agents, since the effects of a good number of the financial variables on real magnitudes are non-linear.

Accordingly, most existing macroeconomic models are lacking a financial block, but they are supplemented with the results obtained from other, more partial modellings ${ }^{6}$, ones which allow a more detailed treatment of specific aspects, including financial aspects. Within these equations, which we might call satellite equations, are those that study the determinants of credit to different agents, in particular households.

For these satellite models, a multiequational approach is occasionally adopted, as is the case in Martínez-Carrascal and Del Río (2004). These authors illustrate the bidirectional interaction between credit and household spending variables. In other cases, in contrast, a single-equation model is needed, where credit is the only endogenous variable, while the behaviour of its determinants is considered exogenous. This is what happens, for example, under the projection exercises conducted by many central banks, where a general macroeconomic model is taken as a basis and a central scenario for real variables is obtained.

On the basis of these considerations, Nieto (2003) presented a model to analyse the determinants of Spanish household credit. As indicated in this paper and in Malo and Restoy (2004), during the latter years of the sample analysed certain changes were observed in the sensitivity of debt to changes in some of its explanatory variables. In addition, the predictive capacity of that model has deteriorated notably in recent years, affected also by the fact that some exogenous variables have altered as a result of the changes introduced into Spanish National Accounts ${ }^{7}$. Accordingly, this paper presents an alternative modelling that resolves these problems.

The rest of the paper is structured as follows. The second section briefly reviews the literature on the determinants of household financing. The third section presents the findings of the estimation of a single-equation empirical model for household borrowing, comparing it with that existing to date. Finally, the fourth section draws the main conclusions.

5. For more detailed information see the book The analysis of the Spanish Economy. Data, instruments and procedures, Banco de España (2005).

6. For example, see Sastre and Fernández-Sánchez (2005)

7. See Banco de España (2005 b). 


\section{Review of the literature on the determinants of household financing}

\subsection{Theoretical determinants}

From a theoretical standpoint, changes in credit obtained by households are linked both to supply- and demand-side factors. However, in many cases it is very difficult to isolate both channels, since the different variables that may help explain the behaviour of financing simultaneously effect the supply of and demand for loanable funds.

As one of the main determinants of recourse to credit, the theoretical and empirical literature indicates the so-called scale variables: expenditure, income or economic activity, which proxy for the permanent income concept. In this respect, households can resort to the credit market to obtain funds with which to meet their consumption and investment decisions when these cannot be financed by their current level of income. In addition, the impact that the business cycle may have on financial institutions' lending policies must be taken into account as it bears on these institutions' perception of the macroeconomic risks prevailing at each point in time.

A second relevant factor concerns the cost of financing, changes in which have an adverse bearing on the demand for loans. Regarding supply, the ultimate result is uncertain. On one hand, there will be a positive impact on the volume of loanable funds provided that a rise in interest rates increases the net interest income obtained by credit institutions. But, on the other, a credit rationing situation may come about, as indicated by Stiglitz and Weiss (1981), insofar as the financial sector might perceive greater risks associated with an increase in the cost of loans.

In this respect, an important factor when assessing household creditworthiness, and therefore the risks borne by financial institutions on extending fresh credit, relates to the financial position of the sector. Thus, for example, an increase in household real estate wealth may reduce the asymmetrical information problems in this market ${ }^{8}$, as such wealth acts as collateral in a very large proportion of loans, making credit institutions readier to extend fresh financing to the sector, in a similar fashion to the mechanism described in the balance-sheet channel literature in the case of companies ${ }^{9}$. Also, inasmuch as wealth may be a proxy for the permanent income concept, an increase in this variable would tend to raise households' borrowing capacity.

Other factors that play a determining role in changes in borrowing relate to the development and liberalisation of the financial sector, and to the better control and management of the risks assumed by financial institutions. Greater competition between banks and financial innovation has thus led to the emergence of new instruments (floating-rate loans, variable-maturity loans, securitisation) that allow both credit supply and demand to be higher and under more favourable financial conditions ${ }^{10}$. However, the measurement of these factors is complex.

Lastly, demographic and labour market-related factors are also possible determinants of household borrowing. In this sense, an increase in household debt may

8 For greater detail, see lacoviello (2005).

9. For example, see Bernanke, Gertler and Gilchrist (1996).

10. See Muellbauer and Murphy (1997) for UK and Bennett, Peach and Peristiani (2001) for US. 
be driven, for example, by growth in employment or by a change in demographic composition towards households with a greater propensity to indebtedness. It should be borne in mind that, insofar as credit constraints are in place, these factors may have non-linear effects. Thus, for instance, an increase in employment may translate into a rise in household debt not only because of the associated growth in their expected income but also owing to the lifting of the restrictions on the unemployed regarding access to the credit market.

\subsection{Empirical evidence}

Firstly, it should be pointed out that the empirical evidence on the determinants of household borrowing using aggregate data is not very extensive owing to information availability problems. Consequently, most papers have focused on analysing household debt and non-financial companies jointly.

For this reason, some studies have resorted to microeconometrics to examine household debt using the information provided by the surveys on the sector conducted by certain countries. Tudela and Young (2005) for the United Kingdom, or Magri (2002) for Italy, find that variables such as income, wealth and interest rates play a significant role when explaining household debt. In this connection, Spain has the Encuesta Financiera de las Familias (Survey of Household Finances), although only the 2002 survey is available, which makes it impossible at present to conduct a study of this type.

As regards empirical analyses with aggregate data, the approach traditionally adopted has been to study the factors behind the various agents' demand for financing, assuming that the volume of credit available is determined by demand, which is provided in an elastic fashion by credit institutions. Some papers have highlighted the need to incorporate characteristics intrinsic to the credit market [e. g., Blundell and Gizycki (1992)], but information availability problems and the difficulty of isolating factors that affect, exclusively, the supply and demand curves have limited the application of this approach.

Accordingly, a large proportion of the studies conducted have adopted a more pragmatic position, incorporating all those elements of relevance in explaining credit developments, ruling out the identification of supply and demand factors in separation, and pointing out that the different variables incorporated reflect both effects.

An initial group of studies estimated models without delving into the potential interrelatedness of real and financial variables, incorporating a long-run relationship where the scale variable was assumed to be exogenous. Thus, for the Spanish case, the results obtained in Manrique and Sáez (1998), Del Río (2002) and Nieto (2003) show that, in the long run, household debt depends positively, and in all cases with a coefficient higher than unity, on the indicator of activity, and negatively on the cost of financing.

Other papers do consider the possible simultaneousness of household spending and borrowing, and duly incorporate vector error correction models. Such is the case of the papers by Chrystal and Mizen (2001) for British households, and by Martínez-Carrascal and Del Río (2004) for Spanish households. In both instances a long-run relationship is found for credit in which it depends positively on household consumption and wealth, and negatively on interest rates. These studies also ascertain which variables adjust and in what proportion when credit and/or consumption deviate from their long-run paths. 
Another important group of studies, as mentioned at the start of this section, has focused on analysing non-financial private-sector indebtedness ${ }^{11}$, estimating Vector Auto Regression (VAR) models with a long-run relationship in which credit is the only endogenous variable. Among these we can highlight those by Calza et al. (2001 and 2003) for the whole of the euro area and by Hofmann (2001) for a set of more industrialised countries. In both cases credit is found to depend positively on GDP, with an elasticity around 1.5, and negatively on the cost of borrowing (in this case there is greater dispersion in the coefficients obtained). In addition, Hofmann conducts a comparative analysis of the estimated equations incorporating the price of housing, so as to see whether changes in property prices help better explain developments in financing. In virtually all countries, with the exception of Spain, this variable proved significant, with a positive relationship being obtained between household credit and household wealth, proxied by house prices. Nonetheless, for the case of Spain, subsequent papers, such as that by Gimeno and Martínez-Carrascal (2006) which analyses the possible bidirectional interaction between credit for house purchases and property prices, find there is interdependence between both variables. The results obtained also show that disequilibrium situations relative to their long-run equilibrium paths entail adjustments in both endogenous variables. This highlights the importance that the behaviour of the property sector has had on household financing developments.

11. Encompasses households and NPISHs and non-financial corporations. 
This section presents the results of the estimation of a single-equation model for credit extended by resident financial institutions to households. Specifically, the following error correction model has been estimated:

$$
\Delta y_{t}=k+\alpha\left(y-\underline{\beta}^{\prime} \underline{x}\right)_{t-1}+\delta(L)\left[\Delta y_{t}, \Delta \underline{x}_{t}\right]+\varepsilon_{t}
$$

where $y$ is the logarithm of the outstanding balance of credit in real terms, deflated by the $\mathrm{CPI}$, and $\underline{x}$ is the vector of explanatory variables. This formulation includes both a long-run relationship, $\beta \underline{x}$, and the short-run dynamic which is captured with the function of variables in differences, $\delta($.$) , and with the error correction term \alpha\left(y-\beta^{\prime} \underline{x}\right)_{t-1}$.

\subsection{Specification of the model}

The model presented in Nieto (2003) has been taken as a starting point, introducing new variables on the basis of the theoretical considerations made in section 2 . The model finally chosen includes the following regressors: as a scale variable, household consumption plus household residential investment ${ }^{12}$; as the cost of loans, the interest rate on the sector's new credit business ${ }^{13}$; the sector's total gross wealth (financial plus real estate) as an indicator of the household financial position; the repayment term for outstanding credit ${ }^{14}$ in order to show some additional supply-side conditions to those directly included by the cost of loans; and, lastly, the interest rate on long-term debt, potentially reflecting current expectations about the future course of the cost of borrowing and of the overall economic situation. In addition, qualitative variables related to the credit restrictions in the late 80 s have been included. Credit, the scale variable and wealth are in logarithms and in real terms ${ }^{15}$, while the remaining regressors are in levels and in nominal terms, with the exception of long-term rates, which have been deflated by actual inflation at each point in time.

That the interest rate on bank loans in nominal terms, and not in real terms, is included is related to the fact that, in addition to proxying the cost of borrowing, this variable would also be reflecting the potential influence of factors relating to the supply of credit. In particular, the volume of funds that financial institutions will be prepared to lend usually observes a prudential criterion which establishes that the initial amount of the loan should not exceed a specific percentage of the borrower's current income. The degree of restriction imposed by this criterion depends on the nominal interest rate, on the term of the loan and on the individual's current income ${ }^{16}$.

As regards the wealth variable, its inclusion in the long-run relationship is new compared with the model estimated in Nieto (2003), in which it was not statistically significant.

12. Other scale variables, such as income, were considered. The results obtained were similar to those presented in this paper.

13. This interest rate is constructed as a weighted average of the cost of bank financing for house purchases by households and the related cost of credit for consumption and other purposes. The weights used are obtained from the breakdown of loans according to purpose. The information on interest rates on new business has been available since 2003. Prior to that the series has been reconstructed on the basis of a synthetic rate for credit institutions' total lending operations.

14. Calculated as a weighted average of the terms of the various types of credit according to purpose.

15. The CPI is used as a deflator, except for consumption and residential investment, where the related deflator is employed.

16. For greater detail see the annex in Martínez-Carrascal and Del Río (2004). 
In this respect, household total wealth and, in particular, household real estate wealth has expanded most substantially in the past decade as a result of the high growth in house prices. Insofar as property is households' main collateral for obtaining financing, and in a setting in which loans for house purchases have, on average, entailed $65 \%$ of the total loans extended by credit institutions to households, developments in the property sector may clearly have played a fundamental role in explaining the increase shown by household debt in Spain ${ }^{17}$.

Further, and with the aim of reflecting other supply-side factors, which have traditionally been difficult to introduce into aggregate-level equations, the long-run relationship incorporates the repayment term for outstanding credit, which has practically doubled over the period analysed. The inclusion of this variable is also new compared with the model estimated in Nieto (2003).

\subsection{Main results}

The existence of a well-defined long-run relationship between the variable to be explained and its regressors requires, firstly, that the variables at play in this relationship should have the same degree of integration. To analyse this, the augmented Dickey-Fuller (ADF) and Phillips-Perron (PP) tests have been used. The results, shown in Table 1, indicate that for variables in levels the null hypothesis of the existence of a unit root cannot be rejected. For the first difference this hypothesis is clearly rejected, except for credit and for consumption plus residential investment, where the results of the two tests are less conclusive.

In order to determine the number of cointegrating relationships, I estimated a VAR model $^{18}$. According to the results, presented in Table 1 , both, the trace statistic and the maximum eigenvalue test support the hypothesis of one cointegrating relationship, when small sample correction is used.

On the basis of these considerations, a model with an error correction mechanism has been estimated by means of the one-stage estimation procedure. As can be seen in Table 2, a long-run equilibrium relationship is found in which credit depends positively on consumption plus residential investment, on wealth and on the repayment term, and negatively on the cost of obtaining the funds and on the unemployment rate. That is to say, households tend to increase borrowing when faced with increases in their spending or situations of low unemployment, which normally coincide with cyclical upturns, and also in the event of an improvement in the terms of access to financing, which may be linked to an increase in household wealth, to greater repayment terms for the credit applied for and/or to the lower cost of this debt. In the short run, movements in long-term government debt yields, which may be informative as to expectations about how interest rates and the general economic situation are evolving, show a negative relationship to the changes in household loans, and the same sign as that shown by the change in the unemployment rate. Lastly, the fourth lag of the endogenous variable reflecting the seasonal behaviour of household financing is included.

17 For a more detailed analysis of the interaction between house prices and credit, see Gimeno and Martínez-Carrascal (2006).

18. The model included two lags of endogenous variables in levels (credit, consumption plus household residential investment, wealth, interest rate, unemployment rate and the repayment term of outstanding credit). 
Regarding the values of the estimated coefficients, it should first be pointed out that the velocity of adjustment $(-0.27)$ is almost double that obtained in previous papers for Spanish households [Del Río (2002) and Nieto (2003) $)^{19}$ ] and almost four times that obtained, for example, by Calza et al. (2001 and 2003), in estimations for total credit to the non-financial private sector in the euro area. That would be reflecting the fact that the response of debt in restoring long-run equilibrium is fairly rapid, with the observed deviation being corrected in a year. Also, the cointegration test based on the $t$ statistic of the error correction mechanism does not enable the null hypothesis of cointegration for the long-run relationship to be rejected at the $1 \%$ significance level20.

As regards the long-run relationship, the elasticity of consumption plus residential domestic investment is below one and lower than that obtained in the other papers mentioned here, although in most cases the scale variable used has differed (household income or GDP). This result is, however, in line with money demand studies that also include wealth as a determinant in the long-run relationship. Therefore, the low elasticity of the scale variable is possibly related to the complementary role played by expenditure and wealth in proxying household permanent income. As to the cost of borrowing, the estimated effect $(-1.6)$ is less than that obtained in specifications for Spanish households [Manrique and Sáez (1998) and Nieto (2003)], although it is close to the values obtained in papers on credit to the private sector in the euro area [Calza et al. (2001)] or the paper by Hofmann (2001) for various industrialised countries.

As far as the wealth variable is concerned, the estimated value for the coefficient $(0.62)^{21}$ is at an intermediate point between the figure of 0.48 obtained by Martínez-Carrascal and Del Río (2004) and that of 0.78 by Gimeno and Martínez-Carrascal (2006) in estimations made for Spain ${ }^{22}$. It is also in the proximity of the results of Hofmann (2001) in equations, for various industrialised countries, of the determinants of credit to the private sector that included house prices as a regressor.

The estimated parameter for the repayment term of outstanding credit means that an increase of one year in the repayment period entails an increase of $2.3 \%$ in the long-run equilibrium level of household loans. Lastly, a negative coefficient with a value in line with that estimated in Del Río (2002) and Nieto (2003) is obtained for the unemployment rate.

The specification tests are relatively satisfactory. The cointegration hypothesis is not rejected, while the intra-sample stability of the parameters is reasonable and there does not appear to be significant autocorrelation in the residuals. To evaluate the predictive power of the model23, forecasting errors at different horizons have been calculated, both within and out of the sample for the period running from 2005 Q1 to 2006 Q2. Using the mean square error as an indicator, errors committed for horizons between one and six periods ahead stand at around $0.5 \%$ of the average level of the series both for in-sample and out-of-sample forecasting. In addition, in terms of the growth rate of household credit, the errors in out-of-sample forecasting in no circumstances exceeded one percentage point

19. In the rollover analysis presented in Nieto (2003) to see the stability of the parameters, it could be seen that in recent years the coefficient had increased considerably, standing at levels close to those obtained in the current model.

20. The critical values presented in Banerjee et al. (1998) have been taken.

21. The value of this coefficient is close to the average loan-to-value ratio of loans granted by credit institutions to households between 2004 and 2006 (63\%).

22. In the latter case the higher value may be due to the fact that the endogenous variable used is only credit for house purchases, which is more collateralised than other credit.

23. This factor is important as the model estimates may be used for the different forecasting exercises conducted at the Banco de España. 
during the 18-month period analysed ${ }^{24}$. As can be seen in Chart 3, comparison of the predictive power of the model presented here compared with that estimated in Nieto (2003) shows a substantial improvement, as notably lower forecasting errors are obtained.

The estimation performed entails an increase in the equilibrium level of credit during the period considered, which would be reflecting the adaptation of household spending decisions to the new macroeconomic environment stemming from euro area membership and from the reforms undertaken in the labour market. In addition, the substantial reduction in the cost of borrowing, combined with the growth of household wealth and the liberalisation of and heightened competition in the banking industry, which has prompted a more expansionary lending policy, has resulted in greater possibilities for Spanish households to take on debt. As can be seen in Chart 4, household debt has increased during the period analysed in line with the estimated equilibrium path, standing in 2006 slightly above this path ${ }^{25}$.

To assess the relative significance of the effect that the various explanatory factors have had on developments in household credit, Chart 4 shows the contribution of the determinants to household debt growth. The sizeable and growing contribution of wealth is noteworthy, having risen from accounting for around 30\% of the expansion in household financing in the late 90 s to over $60 \%$ in the past three years. The rise in household spending has also played a key role, contributing an average in the past decade to around $30 \%$ of the growth in household loans. As to the cost of borrowing, this made a significant positive contribution between 1996 and 1999, but one which came to a halt in the following years owing to the rise in interest rates; subsequently, the fresh decline in the cost of loans once again fuelled the expansion in household borrowing, albeit to a lesser extent than in the late 90s, contributing in a very limited and even non-existent way as a result of the change in monetary policy stance that has occurred in the recent period. The repayment term has helped explain part of the substantial growth recorded since 2000 , as the residual maturity of outstanding credits has increased in this period by more than four years. That has enabled households to obtain a greater volume of funds without increasing the financial burden associated with this debt excessively. Lastly, the significant job creation recorded in the past decade, albeit with discrete decreases, has also contributed positively, by around $7.5 \%$ on average, to the expansion of household financing. The unexplained component is generally fairly small, accounting on average over the past 10 years for $1 \%$ of the course of the endogenous variable.

\subsection{Stability analysis}

Unlike in Nieto (2003), in this case there is no evidence of instability of the parameters estimated. To analyse this, several types of exercises have been conducted. First, a test was performed on the recursive residuals using the CUSUM and CUSUMQ statistics, the indication being in both cases that the null hypothesis of stability is not rejected (see Chart 5).

In addition to these joint tests on the model's stability, a recursive estimation of the coefficients has also been made on the basis of the first 49 observations, adding an additional figure each time. As can be seen in Charts 6 and 7, the parameters have not changed substantially in the period under study. However, the problem with this analysis is that the weight of the last observations introduced is not very big relative to the history of the series,

24. Actual average year-on-year growth in the last six quarters was $20.5 \%$.

25. It should be recalled that this analysis is usually conducted assuming that, on average, credit has not deviated from the level implied by fundamentals during the period analysed, i.e. the average deviation is zero. 
whereby the estimated coefficients tend to reflect the changes very slowly. In an attempt to correct this, rollover estimates have been made in which a constant-size moving sample of 49 observations is used. In this way the problem with the previous approach is avoided, although the results should be interpreted with caution since, as a smaller sample is involved, the confidence bands of the parameters estimated are fairly large. In any event, the results obtained did not actually show significant changes in the coefficients obtained. The only point of note would be the increase in the sensitivity of credit to the cost of financing and to the unemployment rate. In both cases this result may be associated with the non-linear effect of both variables on the demand for funds, and it might be a reflection of the lessening of the restrictions to which a specific group of households might have been subject in the past. The significant reduction in interest rates and in the unemployment rate during this period has thus led to a substantial number of households, previously denied access to the credit market, being able now to resort to it, thereby increasing the effect that these variables have on financing.

In sum, the results of the tests performed for the sample as a whole indicate that the relationships derived from the equation presented may be considered stable overall for the period analysed. 


\section{Conclusions}

The potential consequences that changes in credit extended to households may have for an economy's macroeconomic and financial stability make it necessary to have tools at hand providing for the ongoing analysis and assessment of credit developments, and for the obtaining of forecasts on its future behaviour. In this connection, this paper estimates a single-equation model for household borrowing, consistent with a working framework in which the determinants are set exogenously by a general macroeconomic model.

The results obtained indicate that household financing is determined in the long run by the sector's real spending, its gross wealth and the repayment term of outstanding loans, which exerts a positive influence, and by the cost of loans and the unemployment rate, the influence of which is of a negative sign. Short-term developments are influenced by changes in long-term rates and in employment.

The evidence provided in this paper suggests that, generally, financing received by households in the period analysed is in line with what may be inferred from fundamentals. Thus, the significant increase in household wealth, combined with considerably buoyant household spending, with the environment of greater macroeconomic stability -which made for a substantial decline in interest rates and for higher levels of employment- and, moreover, with financial institutions' more expansionary lending policies, appear to have played a key role when explaining the expansion of households' borrowed funds.

Nonetheless, this should not mask the fact that the high volume of debt attained entails greater exposure of households to unexpected changes in their income, their wealth or the cost of financing, especially against a background in which floating-rate loans are increasingly significant. Indeed, on aggregate data, saving not earmarked for debt service ${ }^{26}$ has fallen continuously since 1995, and even turned negative in 2006.

In any event, a complete assessment would require complementing this analysis with others of a more microeconomic nature on the distribution of debt, income and wealth in the total population ${ }^{27}$, in order to identify specific groups of agents who are in situations of greater vulnerability than that prevailing for the sector as a whole.

Finally, it should be pointed out that the foreseeable course of the main determinants of credit does not seem compatible with a nominal growth rate of around $20 \%$. Accordingly, the rate of increase of household financing will have to moderate substantially to prevent the high level of debt from becoming excessive and ultimately having an adverse impact on household consumption and residential investment.

26. Obtained as household gross saving less repayment of the debt incurred.

27. For a more detailed analyses, see the article "Survey of Household Finances (EFF): description, methods and preliminary results" in Economic Bulletin, January 2005, Banco de España. 


\section{REFERENCES}

BANCO DE ESPAÑA (2005 a). The analysis of the Spanish Economy. Data, instruments and procedures, Servicio de Estudios.

- (2005b). "La Contabilidad Nacional de España, Base 2000; principales cambios e implicaciones para los agregados macroeconómicos", Economic Bulletin, June, Banco de España.

- (2005c). "Survey of Household Finances (EFF): description, methods and preliminary results", Economic Bulletin, January, Banco de España.

BANERJEE A., J. J. DOLADO and R. MESTRE (1998). "Error-correction mechanism tests for cointegration in a single-equation framework", Journal of time series analysis, Vol. 19, No. 3, May, pp. 267-283.

BENNETT, P., R. PEACH and S. PERISTIANI (2001). "Structural change in the mortgage market and the propensity to refinance", Journal of money, credit and banking, 33 (4), pp. 955-975.

BERNANKE B., M. GERTLER and S. GILCHRIST (1996). "The financial accelerator and the flight to quality", Review of Economic and Statistics, 78, pp. 1-15.

BLUNDELL, A., and M. GIZYCKI (1992). Credit supply and demand in the Australian economy, Research Discussion Paper No. 9208, Reserve Bank of Australia.

CALZA, A., C. GARTNER and J. SOUSA (2001). Modelling the demand for loans to the private sector in the euro area, Working Paper No. 55, European Central Bank. Also in Applied Economics, January 2003, 35 (1), pp. 107-117.

CALZA, A., M. MANRIQUE and J. SOUSA (2003). Aggregate loans to the euro area private sector, Working Paper No. 202, European Central Bank.

CHRYSTAL, A., and P. MIZEN (2001). Consumption, money and lending: a joint model for the UK household sector, Working Paper No. 134, Bank of England.

DAVIS, E. P. (1992). "Financial Fragility in the Personal Sector", Chapter 3 in Debt, Financial Fragility, Systemic Risk, Clarendon Press Oxford.

DEL RIO, A. (2002). El endeudamiento de los hogares españoles, Working Paper No. 0228, Banco de España.

GIMENO, R., and C. MARTÍNEZ-CARRASCAL (2006). The interaction between house prices and loans for house purchase. The Spanish case, Working Paper No. 0605, Banco de España.

HOFMANN, B. (2001). The determinants of private sector credit in industrialised countries: do property prices matter?, Working Paper No. 108, BIS.

IACOVIELLO, M. (2005). "House prices, collateral constraints and monetary policy in the business cycle?", American Economic Review, 95 (3), pp. 739-764.

MAGRI, S (2002). Italian Households' debt: determinants of demand and supply, Temi di Discussione No. 454, Banca D'Italia.

MALO DE MOLINA, J. L., and F. RESTOY (2004). Recent trends in corporate and household balance sheets in Spain: macroeconomic implications, Occasional Paper No. 0402, Banco de España.

MANRIQUE, M., and F. SÁEZ (1998). "Un análisis desagregado de la demanda de activos líquidos y de la demanda de crédito de las familias y de las empresas no financieras", Economic Bulletin, March, Banco de España.

MARTINEZ-CARRASCAL, C., and A. DEL RIO (2004). Households borrowing and consumption in Spain: a VECM approach, Working Paper No. 0421, Banco de España.

MUELLBAUER, J., and A. MURPHY (1997). "Booms and busts in the U.K. housing market", Economic Journal, November, 107, pp. 1701-1727.

NIETO F. (2003). "Determinantes del crecimiento del crédito a los hogares en España”, Economic Bulletin, April, Banco de España.

NIETO F., A. DEL RIO and T. SASTRE (2001). "La evolución reciente del crédito al sector privado en España. Algunas implicaciones", Economic Bulletin, June, Banco de España.

SASTRE T., and J. L. FERNÁNDEZ-SÁNCHEZ (2005). Un modelo empírico de las decisiones de gasto de las familias españolas, Working Paper No. 0529, Banco de España.

STIGLIZ J., and A. WEISS (1981). "Credit rationing in markets with imperfect information", American Economic Review, 71, pp. 393-410.

TUDELA, M., and G. YOUNG (2005). The determinants of household debt and balance sheets in the United Kingdom, Working Paper No. 266, Bank of England. 
CREDIT (a)

(Year-on-year growth and contributions)

CONSUMER CREDIT AND OTHER LENDING

LENDING FOR HOUSE PURCHASE

- TOTAL

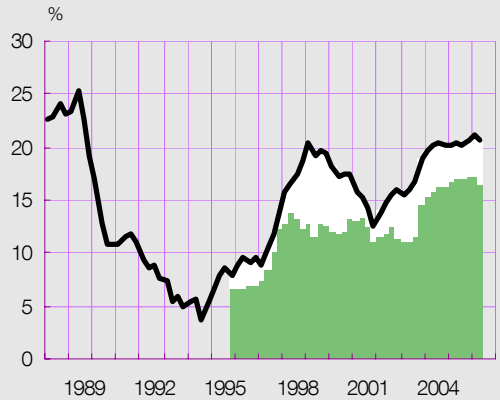

INDEBTEDNESS AND DEBT BURDEN

DEBT RATIO

— TOTAL DEBT BURDEN (right-hand scale)

INTEREST PAYMENTS (right-hand scale)

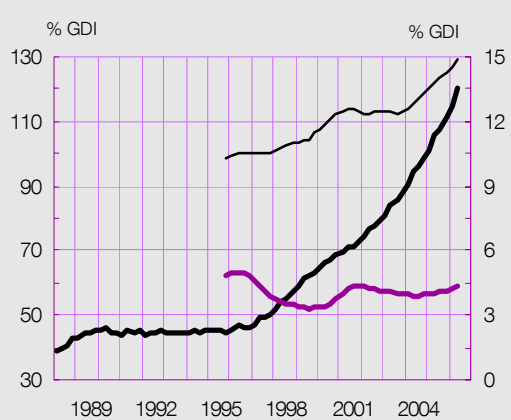

SOURCE: Banco de España.

a. Includes off-balance-sheet securitised loans. Prior to 1995 there is no comparable information. available on the various end-uses of credit. 
CONSUMPTION AND RESIDENTIAL INVESTMENT (in real terms). YEAR-ON-YEAR GROWTH

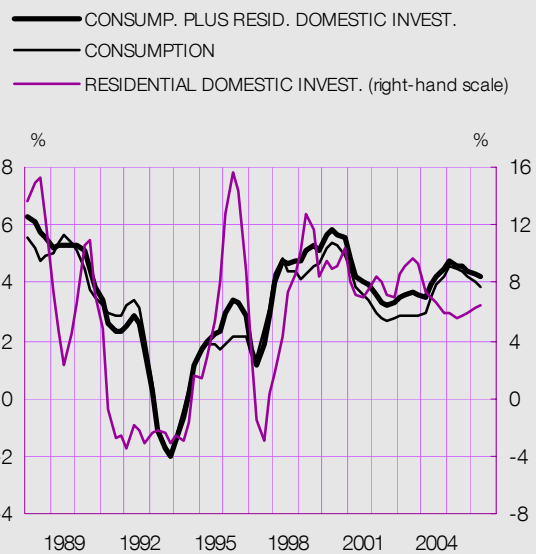

HOUSEHOLD WEALTH (in real terms).

YEAR-ON-YEAR GROWTH
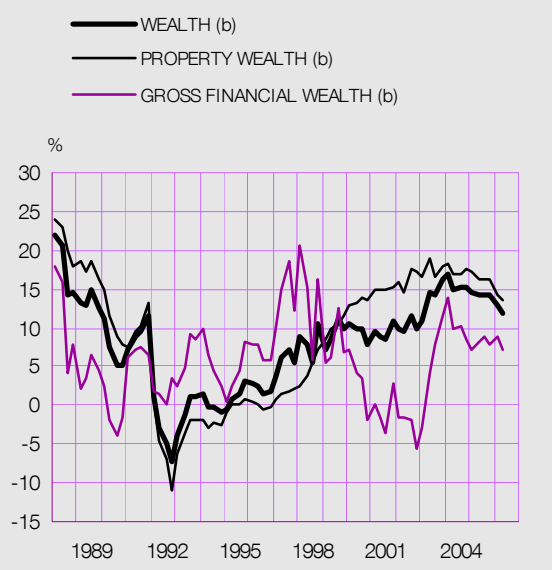

INTEREST RATES AND MATURITY
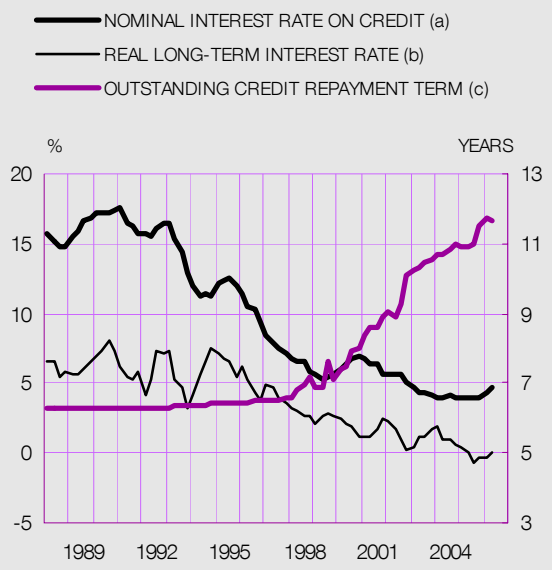

UNEMPLOYMENT
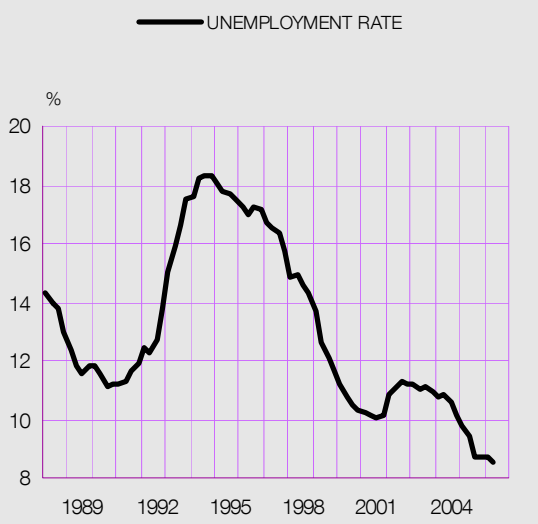

SOURCE: Banco de España.

a. Calculated as a weighted average of rates on new business in respect of household lending for house purchases and for consumer credit and other purposes.

b. Deflated by the CPI.

c. Prior to 1993 there is no information available, so the first available figure is repeated. 
YEAR-ON-YEAR GROWTH (a)

- ACTUAL

FORECAST - OLD MODEL

_ FORECAST - NEW MODEL

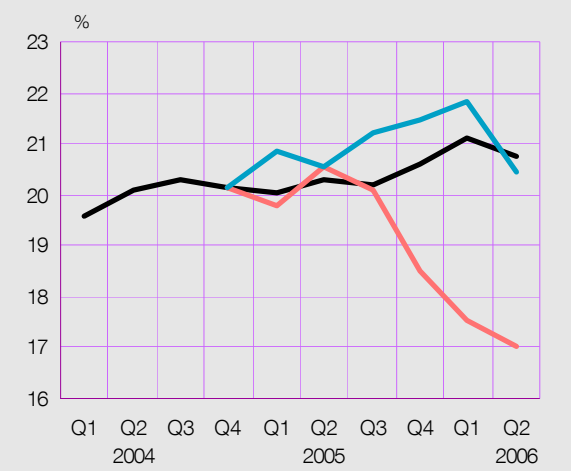

MEAN SQUARE ERRORS (b)

- OLDMODEL NEWMODEL

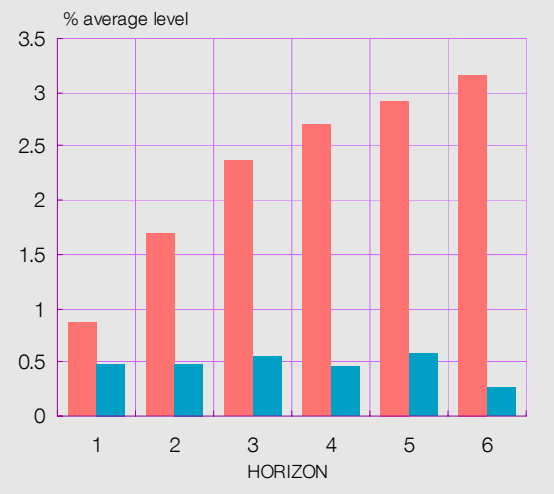

SOURCE: Banco de España.

a. The beginning of the forecast is 2005 Q1.

b. Making forecasts for the period 2005 Q1 - 2006 Q2. 


\section{LONG-RUN PATH AND DEVIATIONS}

DEVIATIONS FROM LONG-RUN PATH (right-

and scale)(a)
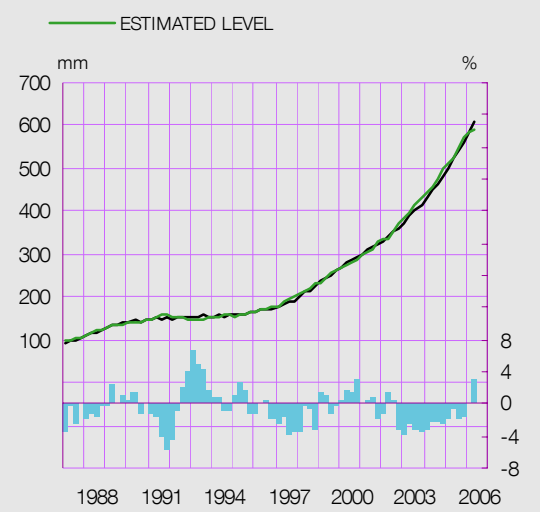

CONTRIBUTIONS TO THE YEAR-ON-YEAR

GROWTH OF CREDIT IN REAL TERMS

$$
\text { OTHER }
$$

ONG-TERM RATE

UNEMPLOYMENT RATE

////// REPAYMENT TERM

WEALTH

CONSUMPTION + RESID. DOMESTIC INVEST.

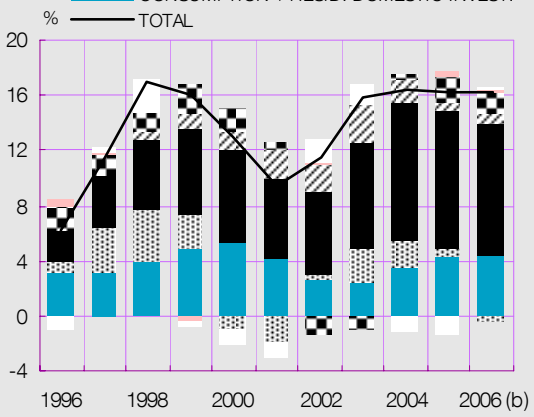

SOURCE: Banco de España.

a. Standardised to obtain a zero average in the sample period.

b. Data to 2006 Q2. 
STANDARDISED CUMULATIVE RECURSIVE RESIDUALS

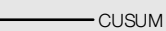

- . . . - - LOWER BAND (b)

- . . . - - UPPER BAND (b)

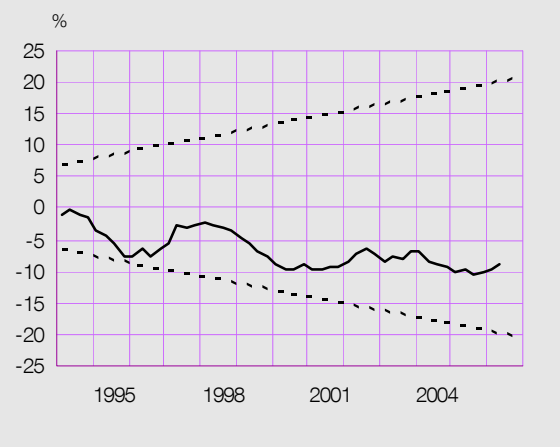

SOURCE: Banco de España.

a. The null hypothesis is stability.

b. At the $5 \%$ significance level.
STANDARDISED CUMULATIVE SQUARED

RECURSIVE RESIDUALS

CUSUMQ

- . . . - LOWER BAND (b)

$\ldots . . . \cdot$ UPPER BAND (b)

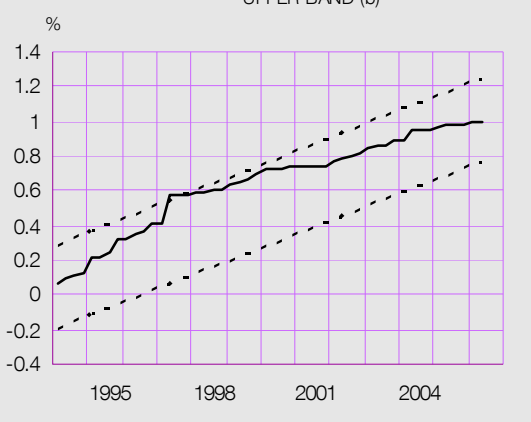




\section{ERROR CORRECTION TERM}

APPROACH 1 (b)

- . - . - $+2 \sigma$

APPROACH 2 (c)

..... +20

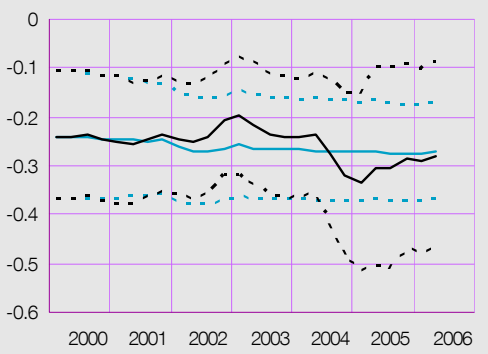

INTEREST RATE ON CREDIT TO HOUSEHOLDS (a)

APPROACH 1 (b)

$-\cdots+\cdots+2 \sigma$
$-\cdots$

- . - . - $-2 \sigma$

APPROACH 2 (c)

$-\cdots+\cdot+2 \sigma$

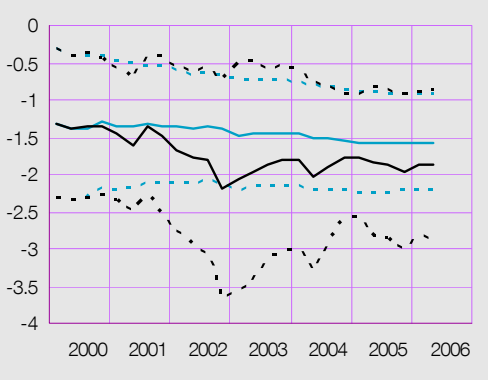

LOAN'S TERM TO MATURITY (a)

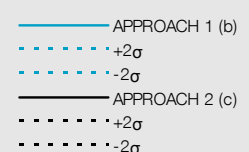

- . - - - - $-2 \sigma$

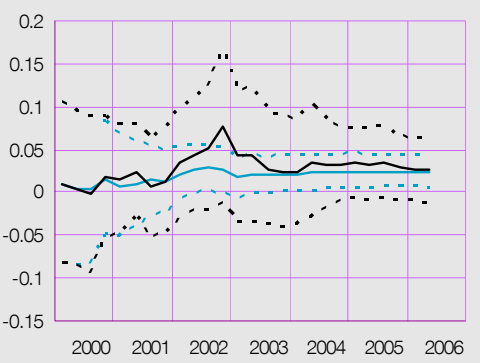

CONSUMPTION + RESIDENTIAL DOMESTIC INVESTMENT (a)

$$
\begin{aligned}
& \text { APPROACH } 1 \text { (b) } \\
& \text { - . . - . + }+2 \sigma \\
& \text { APPROACH } 2 \text { (c) } \\
& \text { - ..... CERO } \\
& \text {. . . . + }+2 \sigma
\end{aligned}
$$

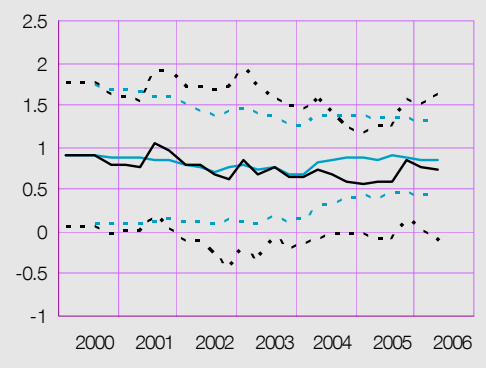

WEALTH (a)

APPROACH 1 (b)

$=-\cdots+\cdot+2 \sigma$

APPROACH 2 (c)

$\cdots \cdots+2 \sigma$

. . . . . - $-2 \sigma$

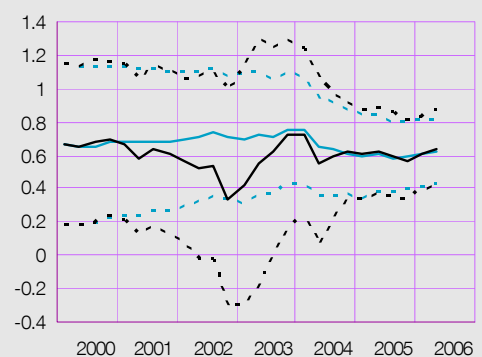

UNEMPLOYMENT RATE (a)

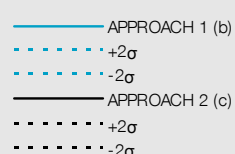

$\cdots \cdot \cdot-20$

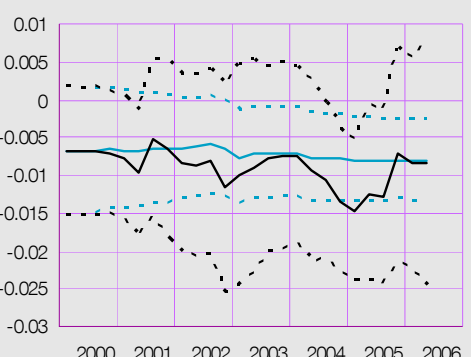

SOURCE: Banco de España.

a. Implicit long-run parameter

b. Recursive estimate based on the first 49 observations

c. Recursive estimate eliminating the oldest observation when a new one is added, keeping the

sample size continuously the same (49 observations). 


\section{LONG-TERM INTEREST RATE}

APPROACH 1 (a)

- . . . . + $+2 \sigma$

$-\cdots \cdot-2 \sigma$

APPROACH 2 (b)

- . - + $+2 \sigma$

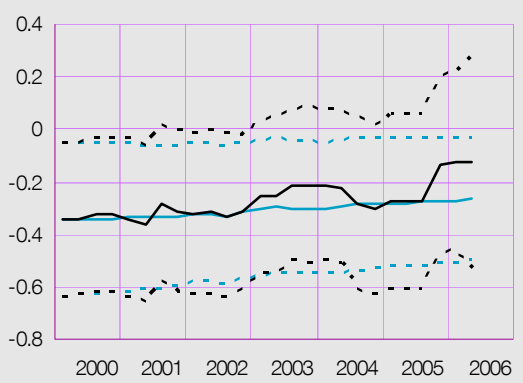

CREDIT

APPROACH 1 (a)

- . - . + $+2 \sigma$

$\cdots-\cdots-2 \sigma$

APPROACH 2 (b)

$\ldots . . .2 \sigma$

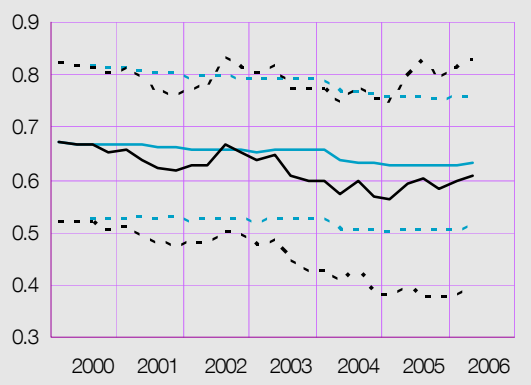

SOURCE: Banco de España.

a. Recursive estimate based on the first 49 observations.

b. Recursive estimate eliminating the oldest observation when a new one is added, keeping the

sample size continuously the same (49 observations). 


\begin{tabular}{|c|c|c|c|c|c|c|c|}
\hline \multirow[t]{3}{*}{ UNIT ROOT TESTS (a) } & \multirow{2}{*}{\multicolumn{3}{|c|}{ Level }} & \multirow{2}{*}{\multicolumn{3}{|c|}{ First difference }} & \multirow{3}{*}{$\begin{array}{c}\text { Order of } \\
\text { integration }\end{array}$} \\
\hline & & & & & & & \\
\hline & No. of lags & ADF & \multirow[t]{2}{*}{ PP } & No. of lags & \multirow[t]{2}{*}{ ADF } & \multirow[t]{2}{*}{$\mathrm{PP}$} & \\
\hline \multicolumn{5}{|l|}{ VARIABLE } & & & \\
\hline Credit (b) & 6 & 1.89 & 1.54 & 3 & -0.59 & $-4.28^{\star \star *}$ & $1 / 2$ \\
\hline Consumption and resid. domestic invest. (b) & 4 & 2.00 & 7.77 & 3 & -2.43 & $-8.07^{\star \star \star}$ & $1 / 2$ \\
\hline Total wealth $(b)$ & 3 & 1.84 & 4.96 & 2 & $-1.75^{\star}$ & $-3.63^{\star \star \star}$ & 1 \\
\hline Nominal interes rate on credit & 6 & $-1.71^{*}$ & -1.36 & 5 & $-2.68^{\star \star \star}$ & $-5.35^{\star \star \star}$ & 1 \\
\hline Repayment term & 0 & 2.56 & 2.85 & 0 & $-8.80^{\star \star \star}$ & $-8.86^{\star \star \star}$ & 1 \\
\hline Unemployment rate & 1 & -1.27 & -1.03 & 0 & $-4.03^{\star \star \star}$ & $-3.99^{\star \star \star}$ & 1 \\
\hline Real long-term interest rate & 0 & -1.16 & -1.13 & 0 & $-7.74^{\star \star \star}$ & $-7.84^{\star \star \star}$ & 1 \\
\hline \multicolumn{8}{|l|}{ JOHANSEN TEST FOR COINTEGRATION (c) } \\
\hline \multicolumn{7}{|l|}{ Unrestricted model } & \\
\hline Ho: rank $=r$ & $\begin{array}{l}\text { I-max test } \\
\text { statistic }\end{array}$ & $\begin{array}{c}\text { small } \\
\text { sample } \\
\text { correction }\end{array}$ & $\begin{array}{c}95 \% \text { critical } \\
\text { values }\end{array}$ & $\begin{array}{l}\text { trace text } \\
\text { statistic }\end{array}$ & $\begin{array}{c}\text { small } \\
\text { sample } \\
\text { correction }\end{array}$ & $\begin{array}{l}95 \% \text { critical } \\
\text { values }\end{array}$ & \\
\hline$r=0$ & $71.16^{\star \star}$ & $59.93^{\star *}$ & 39.40 & $151.3^{\star \star}$ & $127.4^{\star \star}$ & 94.20 & \\
\hline$r \leq 1$ & 33.71 * & 28.38 & 33.50 & $80.11^{\star *}$ & 67.46 & 68.50 & \\
\hline$r \leq 2$ & 26.04 & 21.93 & 27.10 & 46.40 & 39.08 & 47.20 & \\
\hline$r \leq 3$ & 14.92 & 12.57 & 21.00 & 20.36 & 17.15 & 29.70 & \\
\hline$r \leq 4$ & 3.50 & 2.95 & 14.10 & 5.44 & 4.58 & 15.40 & \\
\hline$r \leq 5$ & 1.93 & 1.63 & 3.80 & 1.93 & 1.63 & 3.80 & \\
\hline
\end{tabular}

a. The null hypothesis is the presence of a unit root. ${ }^{* * *},{ }^{* *}$ and ${ }^{*}$ denote the rejection of the null hypothesis at significance levels of $1 \%$, $5 \%$ and $10 \%$ respectively, based on the critical values of Mackinnon (1996). ADF denotes the augmented Dickey-Fuller test (with lags up to and including the highest lag that is statistically significant, at least at the $5 \%$ level), PP denotes the Phillips-Perron test. When a constant is included, it is represented by the letter ' $c$ '.

b. In real terms.

c. The VAR model includes two lags of endogenous variables specified in levels. The constant term is unrestricted. * $\left.{ }^{* *}\right)$ denotes existence of cointegration at $5 \%(1 \%)$ significance level. 


\begin{tabular}{|c|c|c|}
\hline \multicolumn{3}{|c|}{$\Delta \mathrm{C}_{\mathrm{t}}=\mathrm{K}+\alpha\left(\mathrm{C}-\beta_{1} \mathrm{CRDI}-\beta_{2} \mathrm{R}-\beta_{3} \mathrm{~W}-\beta_{4} \mathrm{TERM}-\beta_{5} \mathrm{UR}\right)_{\mathrm{t}-1}+\delta_{1} \Delta \mathrm{C}_{\mathrm{t}-4}+\delta_{2} \Delta \mathrm{UR}_{\mathrm{t}-1}+\delta_{3} \mathrm{LTR}_{\mathrm{t}-1}+\delta_{4} \Delta \mathrm{l} 1+\delta_{5} \Delta \mathrm{I} 2+\varepsilon_{\mathrm{t}}(\mathrm{b})$} \\
\hline & COEFFICIENT & T-VALUE \\
\hline \multicolumn{3}{|l|}{ VARIABLE } \\
\hline Error correction term (a) & -0.27 & -5.56 \\
\hline Consumption plus residential domestic investment ( $\beta 1$ ) (c) & 0.84 & 3.91 \\
\hline Synthetic interest rate of credit to households ( $\beta 2$ ) & -1.58 & -4.89 \\
\hline Total wealth (ß3) (c) & 0.62 & 6.44 \\
\hline Repayment term ( $\beta 4$ ) & 0.02 & 2.56 \\
\hline Unemployment rate $(\beta 5)$ & -0.01 & -3.02 \\
\hline Credit (ס1) (c) & 0.63 & 10.22 \\
\hline Unemployment rate $(\delta 2)$ & -0.003 & -1.23 \\
\hline Real long-term interest rate $(\delta 3)$ & -0.27 & -2.27 \\
\hline Truncated trend 89:03-91:04 (ס4) & -0.01 & -3.05 \\
\hline Step 92:01 (ס5) & -0.05 & -5.35 \\
\hline Constant (K) & -1.74 & -3.00 \\
\hline
\end{tabular}

\section{GOODNESS OF FIT TESTS (c)}

Adjusted R2

DW

$Q(1)$

$\mathrm{Q}(4)$

$\mathrm{Q}(8)$

MSE $t+1$

MSE $t+4$

RESIDUAL TESTS (e)

Normality

a. The estimation is made in one stage. The variables are in logarithms, except for the interest rates, the unemployment rate and the repayment term.

b. $C$ is credit, $C R D I$ is consumption plus residential domestic investment, $R$ is a nominal synthetic interest rate on new business in respect of credit to households, W is real-estate and financial wealth, TERM is the repayment term of households' total outstanding credit, UR is the unemployment rate, LTR is the real rate on ten-year government debt, I are dummies that reflect the effect of credit restrictions, $\mathrm{K}$ is a constant and $\varepsilon$ is the error term.

c. In real terms.

d. R2 is the adjusted coefficient of determination, $\sigma \varepsilon$ is the standard residual error, DW is the Durbin-Watson residual autocorrelation statistic, $Q(k)$ is the value of the Box-Pierce-Ljung statistic of the k-order correlation of the residuals, y MSEt+i is the out-of-sample forecasting error i periods ahead.

e. P-values are in brackets. For normality the Jarque-Bera statisc is used. The LM test is the Godfrey test for autocorrelation. Arch test is for autoregressive conditional heteroscedasticitiy test. The heteroscedasticity test is a White test. 


\section{BANCO DE ESPAÑA PUBLICATIONS}

\section{WORKING PAPERS ${ }^{1}$}

0601 ARTURO GALINDO, ALEJANDRO IZQUIERDO AND JOSÉ MANUEL MONTERO: Real exchange rates, dollarization and industrial employment in Latin America.

0602 JUAN A. ROJAS AND CARLOS URRUTIA: Social security reform with uninsurable income risk and endogenous borrowing constraints.

0603 CRISTINA BARCELÓ: Housing tenure and labour mobility: a comparison across European countries.

0604 FRANCISCO DE CASTRO AND PABLO HERNÁNDEZ DE COS: The economic effects of exogenous fiscal shocks in Spain: a SVAR approach.

0605 RICARDO GIMENO AND CARMEN MARTÍNEZ-CARRASCAL: The interaction between house prices and loans for house purchase. The Spanish case.

0606 JAVIER DELGADO, VICENTE SALAS AND JESÚS SAURINA: The joint size and ownership specialization in banks' lending.

0607 ÓSCAR J. ARCE: Speculative hyperinflations: When can we rule them out?

0608 PALOMA LÓPEZ-GARCÍA AND SERGIO PUENTE: Business demography in Spain: determinants of firm survival.

0609 JUAN AYUSO AND FERNANDO RESTOY: House prices and rents in Spain: Does the discount factor matter?

0610 ÓSCAR J. ARCE AND J. DAVID LÓPEZ-SALIDO: House prices, rents, and interest rates under collateral constraints.

0611 ENRIQUE ALBEROLA AND JOSÉ MANUEL MONTERO: Debt sustainability and procyclical fiscal policies in Latin America.

0612 GABRIEL JIMÉNEZ, VICENTE SALAS AND JESÚS SAURINA: Credit market competition, collateral and firms' finance.

0613 ÁNGEL GAVILÁN: Wage inequality, segregation by skill and the price of capital in an assignment model.

0614 DANIEL PÉREZ, VICENTE SALAS AND JESÚS SAURINA: Earnings and capital management in alternative loan loss provision regulatory regimes.

0615 MARIO IZQUIERDO AND AITOR LACUESTA: Wage inequality in Spain: Recent developments.

0616 K. C. FUNG, ALICIA GARCÍA-HERRERO, HITOMI IIAKA AND ALAN SUI: Hard or soft? Institutional reforms and infraestructure spending as determinants of foreign direct investment in China.

0617 JAVIER DÍAZ-CASSOU, ALICIA GARCÍA-HERRERO AND LUIS MOLINA: What kind of capital flows does the IMF catalyze and when?

0618 SERGIO PUENTE: Dynamic stability in repeated games.

0619 FEDERICO RAVENNA: Vector autoregressions and reduced form representations of DSGE models.

0620 AITOR LACUESTA: Emigration and human capital: Who leaves, who comes back and what difference does it make?

0621 ENRIQUE ALBEROLA AND RODRIGO CÉSAR SALVADO: Banks, remittances and financial deepening in receiving countries. A model.

0622 SONIA RUANO-PARDO AND VICENTE SALAS-FUMÁS: Morosidad de la deuda empresarial bancaria en España, 1992-2003. Modelos de la probabilidad de entrar en mora, del volumen de deuda en mora y del total de deuda bancaria, a partir de datos individuales de empresa.

0623 JUAN AYUSO AND JORGE MARTíNEZ: Assessing banking competition: an application to the Spanish market for (quality-changing) deposits.

0624 IGNACIO HERNANDO AND MARÍA J. NIETO: Is the Internet delivery channel changing banks' performance? The case of Spanish banks.

0625 JUAN F. JIMENO, ESTHER MORAL AND LORENA SAIZ: Structural breaks in labor productivity growth: The United States vs. the European Union.

0626 CRISTINA BARCELÓ: A Q-model of labour demand.

0627 JOSEP M. VILARRUBIA: Neighborhood effects in economic growth.

0628 NUNO MARTINS AND ERNESTO VILLANUEVA: Does limited access to mortgage debt explain why young adults live with their parents?

0629 LUIS J. ÁLVAREZ AND IGNACIO HERNANDO: Competition and price adjustment in the euro area.

0630 FRANCISCO ALONSO, ROBERTO BLANCO AND GONZALO RUBIO: Option-implied preferences adjustments, density forecasts, and the equity risk premium.

1. Previously published Working Papers are listed in the Banco de España publications catalogue. 
0631 JAVIER ANDRÉS, PABLO BURRIEL AND ÁNGEL ESTRADA: BEMOD: A dsge model for the Spanish economy and the rest of the Euro area.

0632 JAMES COSTAIN AND MARCEL JANSEN: Employment fluctuations with downward wage rigidity: The role of moral hazard.

0633 RUBÉN SEGURA-CAYUELA: Inefficient policies, inefficient institutions and trade.

0634 RICARDO GIMENO AND JUAN M. NAVE: Genetic algorithm estimation of interest rate term structure.

0635 JOSÉ MANUEL CAMPA, JOSÉ M. GONZÁLEZ-MÍNGUEZ AND MARÍA SEBASTIÁ-BARRIEL: Non-linear adjustment of import prices in the European Union.

0636 AITOR ERCE-DOMÍNGUEZ: Using standstills to manage sovereign debt crises.

0637 ANTON NAKOV: Optimal and simple monetary policy rules with zero floor on the nominal interest rate.

0638 JOSÉ MANUEL CAMPA AND ÁNGEL GAVILÁN: Current accounts in the euro area: An intertemporal approach.

0639 FRANCISCO ALONSO, SANTIAGO FORTE AND JOSÉ MANUEL MARQUÉS: Implied default barrier in credit default swap premia. (The Spanish original of this publication has the same number.)

0701 PRAVEEN KUJAL AND JUAN RUIZ: Cost effectiveness of R\&D and strategic trade policy.

0702 MARÍA J. NIETO AND LARRY D. WALL: Preconditions for a successful implementation of supervisors' prompt corrective action: Is there a case for a banking standard in the EU?

0703 PHILIP VERMEULEN, DANIEL DIAS, MAARTEN DOSSCHE, ERWAN GAUTIER, IGNACIO HERNANDO, ROBERTO SABBATINI AND HARALD STAHL: Price setting in the euro area: Some stylised facts from individual producer price data.

0704 ROBERTO BLANCO AND FERNANDO RESTOY: Have real interest rates really fallen that much in Spain?

0705 OLYMPIA BOVER AND JUAN F. JIMENO: House prices and employment reallocation: International evidence.

0706 ENRIQUE ALBEROLA AND JOSÉ M. a SERENA: Global financial integration, monetary policy and reserve accumulation. Assessing the limits in emerging economies.

0707 ÁNGEL LEÓN, JAVIER MENCÍA AND ENRIQUE SENTANA: Parametric properties of semi-nonparametric distributions, with applications to option valuation

0708 ENRIQUE ALBEROLA AND DANIEL NAVIA: Equilibrium exchange rates in the new EU members: external imbalances vs. real convergence.

0709 GABRIEL JIMÉNEZ AND JAVIER MENCÍA: Modelling the distribution of credit losses with observable and latent factors.

0710 JAVIER ANDRÉS, RAFAEL DOMÉNECH AND ANTONIO FATÁS: The stabilizing role of government size.

0711 ALFREDO MARTÍN-OLIVER, VICENTE SALAS-FUMÁS AND JESÚS SAURINA: Measurement of capital stock and input services of Spanish banks.

0712 JESÚS SAURINA AND CARLOS TRUCHARTE: An assessment of Basel II procyclicality in mortgage portfolios.

0713 JOSÉ MANUEL CAMPA AND IGNACIO HERNANDO: The reaction by industry insiders to M\&As in the European financial industry.

0714 MARIO IZQUIERDO, JUAN F. JIMENO AND JUAN A. ROJAS: On the aggregate effects of immigration in Spain

0715 FABIO CANOVA AND LUCA SALA: Back to square one: identification issues in DSGE models.

0716 FERNANDO NIETO: The determinants of household credit in Spain.

\begin{tabular}{|r|c|}
\hline & Unidad de Publicaciones \\
BANCODEESPANA & Alcalá, 522; 28027 Madrid \\
Eurosistema & Telephone +34 91 338 6363. Fax +34913386488 \\
& e-mail: publicaciones@bde.es \\
www.bde.es
\end{tabular}

